\title{
A new species of Pericalus s.str. (Coleoptera: Carabidae, Lebiini) from Vietnam, with notes on some Oriental members of the subgenus
}

\author{
Новый вид Pericalus s.str. (Coleoptera: Carabidae, Lebiini) \\ из Вьетнама с замечаниями о некоторых Ориентальных \\ преставителях подрода
}

\author{
D.N. Fedorenko \\ A.H. Федоренко
}

A.N. Severtsov Institute of Ecology and Evolution, Leninsky pr. 33, Moscow 119071, Russia. E-mail: dmitri-fedorenko@yandex.ru. Институт проблем экологии и эволюции им. А.Н. Северцова, Российская Академия Наук, Ленинский пр-т 33, Москва 119071, Россия.

KEY WORDS: Coleoptera, Carabidae, Pericalus, new species, Vietnam, Oriental Region.

КЛЮЧЕВЫЕ СЛОВА: Coleoptera, Carabidae, Pericalus, новый вид, Вьетнам, Ориентальная область.

ABSTRACT. Pericalus obtusipennis sp.n. from Vietnam is described and illustrated. Key to species of Pericalus (s.str.) is provided. The name P. baehri, nom.n. is proposed to replace $P$. violaceus Baehr, 2000, n. praeocc., non $P$. violaceus Andrewes, $1926=P$. imitator Baehr, 2000, syn.n.

РЕЗЮМЕ. Pericalus (s.str.) obtusipennis sp.n. описан из Вьетнама. Составлена таблица для определения видов Pericalus (s.str.). Для P. violaceus Baehr, 2000, n. praeocc. (non $P$. violaceus Andrewes, $1926=$ P. imitator Baehr, 2000, syn.n.) предложено замещающее название $P$. baehri, nom.n.

\section{Introduction}

Pericalus MacLeay, 1825, the nominate subgenus of the genus and of the subtribe Pericalina, Lebiini, includes 14 Oriental species; just one species, P. ornatus Schmidt-Göbel, 1846 [Jedlička, 1963] has been hitherto known to occur in Vietnam. In this paper we report three more species from Vietnam, including one new to science (described and illustrated below), and provide a key to species of Pericalus s.str.

The acronyms used are: SIEE, the author's reference collection at A.N. Severtsov Institute of Ecology and Evolution, Russian Academy of Sciences, Moscow; ZISP, Zoological Institute, Russian Academy of Sciences, St. Petersburg; ZMMU, Zoological Museum of the Moscow State University.

The following morphometric parameters were used: BL, maximum body length measured between apices of closed mandibles and apices of elytra; D1 and D2, distances between anterior (d1 or 1d1) or middle (d2) discal elytral seta and elytral base; EL, maximum length of elytron, measured from highest point of base to apex; EW, maximum width of elytra; HW, width of head across eyes;
PL, length of pronotum along median line; $\mathrm{PW}$, maximum width of pronotum; PWa, width of pronotum between apical angles; $\mathrm{PWb}$, width of pronotum between basal angles. Measurements were taken using an eyepiece micrometer, to two decimal places. The number of specimens measured (n) is only given for the first ratio in the description. Data on labels of type specimens are in quotes. Provinces of Vietnam and Indonesia are given in italics.

\section{Results}

Pericalus (s. str.) MacLeay, 1825

MacLeay, 1825: 15; Schmidt-Göbel, 1846: 85; Dupuis, 1913 : 82; Andrewes, 1937: 185; Jedlička, 1963: 377; Baehr, 2000: 33.Pericallus Gemminger et Harold, 1868: 154; Chaudoir, 1869: 158.

Type-species: P. cicindeloides MacLeay, 1825, by monotypy.

REDESCRIPTION. Body medium-sized. Colour black to bright metallic blue or violet. Elytra mostly with a pale pattern consisting of 1-2 large round spots or irregular transverse bands, usually with additional small separate spots, sometimes of separate spots only. Legs mostly dark; antennae usually more or less pale, with antennomeres 1-4 infuscate. Microsculpture meshed, isodiametric on head, uneven on pronotum, mostly slightly to strongly transverse in the center of pronotal disc; elytra predominantly with very transverse and rather coarse microsculpture, meshes arranged into (sub)transverse rows, varying in width. Dorsum largely glabrous, sparsely, almost indistinctly ciliate here and there, more densely and more conspicuously ciliate along elytral sides and apices. Ventral side more distinctly ciliate except along middle of hindbody, with several longer setae running along middle of prosternum, including prosternal process. Tarsi moderately pubescent.

Head large, with large protruding eyes, about as wide as or slightly wider than pronotum. Genae long and oblique, meeting both eye and neck at a smoothened obtuse angle. Clypeus transversely hexagonal to nearly trapezoidal, truncate or barely convex at apical margin. Frons with two 

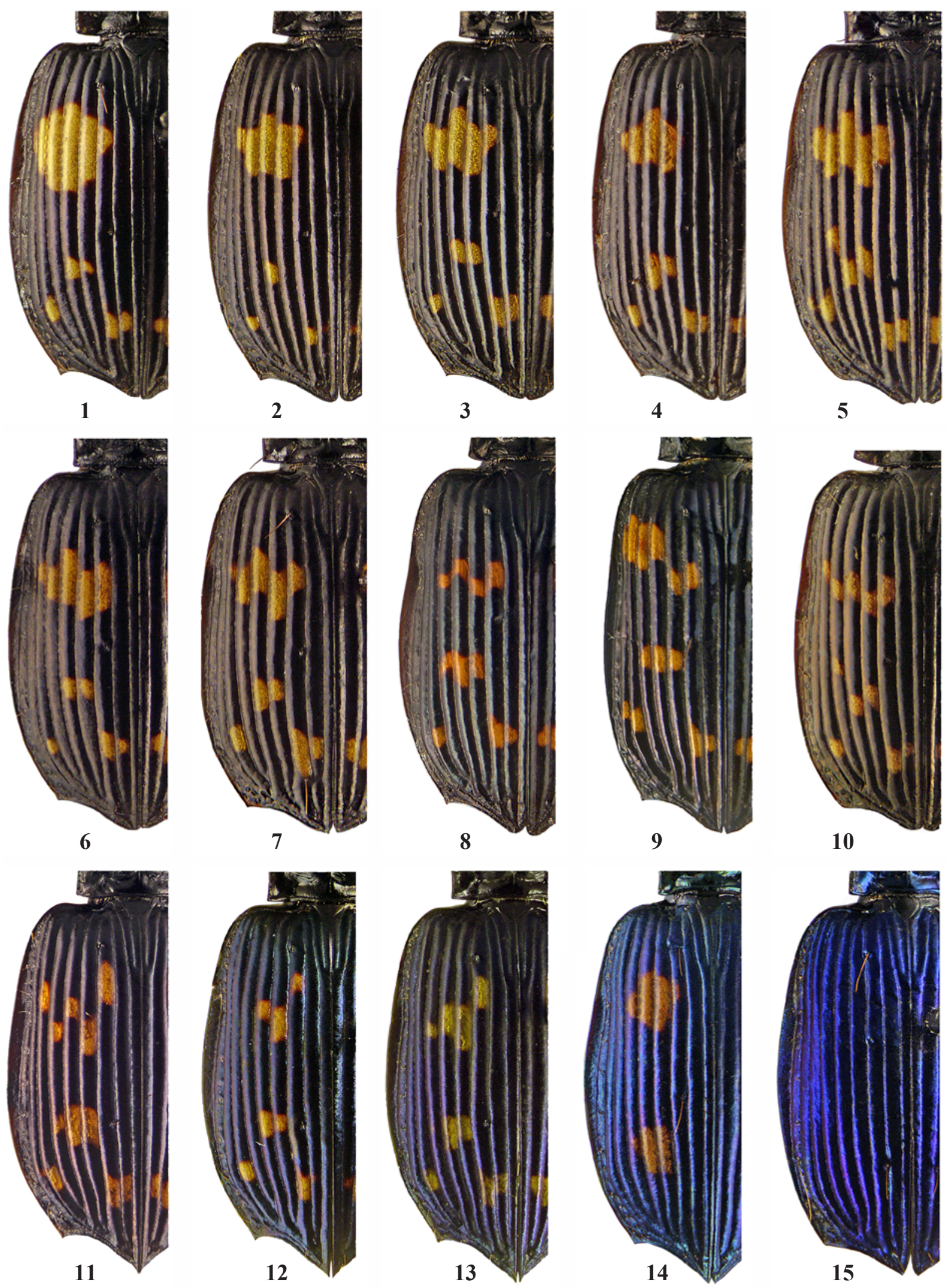

Figs 1-15. Left elytron: 1-4-Pericalus ornatus; 5-P. amplus; $6-7-$ P. formosanus; $8-$ P. funestus; $9-P$. cordicollis; $10-$ P. obtusipennis sp.n.; $11-$ P. guttatus; $12-13-P$. baehri nom.n.; $14-$ P. longicollis; $15-$ P. cicindeloides.

Рис. 1-15. Левое надкрылье: $1-4-$ Pericalus ornatus; $5-$ P. amplus; $6-7-P$. formosanus; $8-P$. funestus; $9-P$. cordicollis; $10-$ P. obtusipennis sp.n.; $11-P$. guttatus; $12-13-$ P. baehri nom.n.; $14-$ P. longicollis; $15-P$. cicindeloides. 
supraocular setae on each side; frontal foveae indistinct or wide and shallow. Neck constriction mostly indistinct or very shallow. Frons and vertex on each side with 5-10 (sometimes 2-3) dense longitudinal carinae that become shorter mesad and diverge slightly basad; outer carina (between anterior and posterior supraocular setae) less developed; intermediate carinae extended forward, abruptly curved just in front of anterior supraocular seta and then strongly diverging to scape condyles; clypeus in basal half with several longitudinal carinae running parallel or slightly diverging forward. Labrum sexsetose, as wide as or slightly wider than long, slightly rounded on sides, more rounded at apical angles; apical margin with a deep fissure-like median emargination often almost reaching the level of lateral setae. Antennae long, with more than apical four segments surpassing elytral bases, pubescent from middle of antennomere 4 onward; scape tapering basad, shorter than eye and barely longer than antennomere 3, which is about a fifth longer than antennomere 4 and more than 2.5 times as long as pedicel. Labial palpiger with a strong seta; penultimate labial palpomere plurisetose at inner margin. Submentum quadrisetose, mentum bisetose; one pair of paragular setae. Mandibles long, slightly curved inwards closer to apex, distinctly, sometimes finely, strigose, including in flat scrobe, rarely smooth; ventral scrobal ridge sharp, dorsal one rectangular.

Pronotum cordate, bisetose on each side. Base entirely beaded, truncate or barely produced medially; apex sinuate, apical bead obliterate medially to throughout. Basal angles sharp, subacute to subrectangular; apical angles separate from neck, projecting forward, acute to widely rounded. Lateral margins explanate and slightly to moderately reflexed; lateral bead obliterate, sometimes traceable throughout or in basal half. Basal transverse impression very deep; basal foveae as short and deep lines slightly converging from basal margin to basal impression and then as very shallow to indistinct sublateral lines extended apicad. Apical transverse impression rather shallow yet distinct. Lateral grooves very shallow to conspicuous. Median line deep, obliterate basally and apically. Paramedian foveae as oblong, large and deep, pits at or slightly before middle, extended to apical impression and sometimes also to basal impression; disc flattened and uneven laterad; another similar yet smaller and shallower impression often located outside paramedian fovea. Disc cross-striated, explanate lateral margin rugose in and outside paramedian foveae.

Elytra (Figs 1-15) short and wide, broadest at or behind the middle; base straight and transverse; humeri distinct, blunt. Apical truncature oblique and deeply sinuate in general; outer angles obtuse to acute, blunt to somewhat pointed; apices widely rounded to mucronate. Basal ridge entire, rarely obliterate inside stria 3; humeral angle obtusely rounded. Lateral margin explanate and slightly reflexed, rather wide at middle, as wide as interval 9; lateral bead very fine. Striae very deep, impunctate or crenulate, intervals convex or very convex. Interval 3 with $3(\mathrm{~d} 1-\mathrm{d} 3)$ or $4(1 \mathrm{~d} 1,2 \mathrm{~d} 1, \mathrm{~d} 2$, and $\mathrm{d} 3)$, occasionally five, large discal setigerous pores; anterior discal seta (d1 or 1d1) mostly in stria 3 near base (D1/EL 0.10-0.17), d3 close to apex, intermediate setae evenly spaced between d1 (1d1) and $\mathrm{d} 3$. Interval 9 with 21-25 umbilical setae arranged in an uninterrupted row, being sparser at middle. Wings full.

Underside smooth, sides of metaventrite finely and densely yet very shallowly to indistinctly punctate. Metepisterna much longer than wide. Abdominal sternites IV-VI with one pair of ambulatory setae, sternite VI quadrisetose in both sexes.

Claws smooth. Metatrochanter with seta, metacoxa with anterolateral seta and inner seta, metafemur bisetose at anteroventral margin. Tarsomere 5 ventrally with $2-3$ pairs of short setae.
Aedeagus (Figs 15-60): median lobe well sclerotized, with apical orifice well-defined and often shifted to the left. Right paramere small, narrow and unciform at base, with apex of different shape depending on species. Internal sac (Figs 6171) with no sclerites but 1-2 basal bulbs, proximal and distal.

Secondary differences between sexes. Males differ from females in the following: protarsomeres 1-3 with ventral adhesive vestiture yet hardly dilated; mesofemur with two preapical tubercles along inner margin; pro- and mesofemora with more or less dense and long erect setae in basal 2/3-3/5 (vs. sparse and/or short setae), the latter difference varying from rather slight ( $P$. amplus) to strong ( $P$. longicollis).

DIAGNOSIS. Pericalus is a peculiar, easily recognizable group within Pericalina. Its closest allies are Coptodera (Coptoderina) Dejean, 1825; Lioptera Chaudoir, 1869 and Trichocoptodera Louwerens, 1958. Gidda Andrewes, 1920 and Stilboma Andrewes, 1933 seem to be more distantly related. All these taxa share mouthparts similarities that include edentate mentum, wide paraglossae extended much beyond ligula, and labial palpiger bearing a strong seta. Additional features are large protruding eyes; abdominal sternite VII quadrisetose in both sexes; often also 3-4 discal setae on elytral interval 3, umbilical setae numerous and arranged in an uninterrupted row. Smooth (vs. serrate or denticulate) tarsal claws differentiate Pericalus from the allied genera.

DISTRIBUTION. Throughout in the Oriental Region: southern and northeastern India and Indochina to southern China (Taiwan), the Philippines and the Sunda Isles.

HABITATS AND HABITS. The members of the subgenus are free-living, arboreal forest dwellers that prefer lowlands and piedmonts. Adults are common on larger tree trunks that lay clear of the ground, occurring also on logs or in crevices between logs and soil. More than one species may be found on the same tree trunk, $P$. formosanus Dupuis, 1913 and $P$. ornatus Schmidt-Göbel, 1846 being just one such example.

COMMENTS. Members of the subgenus Coeloprosopus Chaudoir, 1842 are defined by bright metallic body, small size, and a more or less modified quadrimaculate pale elytral pattern. Besides, the head is finely rugulose ( $v s$. carinate), pronotum very convex, fairly smooth and narrowly beaded laterally, discal elytral setae mostly four, ventral pubescence of pro- and mesofemora similar in sexes, etc. Since Coeloprosopus has recently been revised [Baehr, 1994], we only discuss here the nominate subgenus. Its members are rather uniform in body shape; important species-specific characters include the elytral pattern and number of discal setae.

We hypothesize the relationships between the species based mainly on the combination of four characters: (1) position of apical orifice of aedeagus median lobe (AMLO), (2) shape of the elytral apex, (3) elytral pattern, and (4) number and position of discal elytral setae.

AMLO is either dorsal (Figs 27-32, 38-40) or left-sided (Figs 16-22, 33-35). We presume black body with no or almost no metallic tinge and elytral pattern as in Figs 7-8 to represent the primitive condition. Accordingly, bright metallic dorsum with pale elytral pattern of more than four patches (following either anterior band or some posterior spots broken) or represented by two spots, or lacking, is considered derived. The presence of four discal setae, anterior two (1d1 and $2 \mathrm{~d} 1$ ) in stria $3, \mathrm{~d} 2$ in stria 2 much behind middle, and $\mathrm{d} 3$ close to apex, may be a plesiomorphic character, a similar pattern being typical to the related genera Coptodera and Lioptera. This means that three setae is a derived character, with successive transformations represented by $\mathrm{d} 2$ moving from postmedian to median or premedian position. We con- 

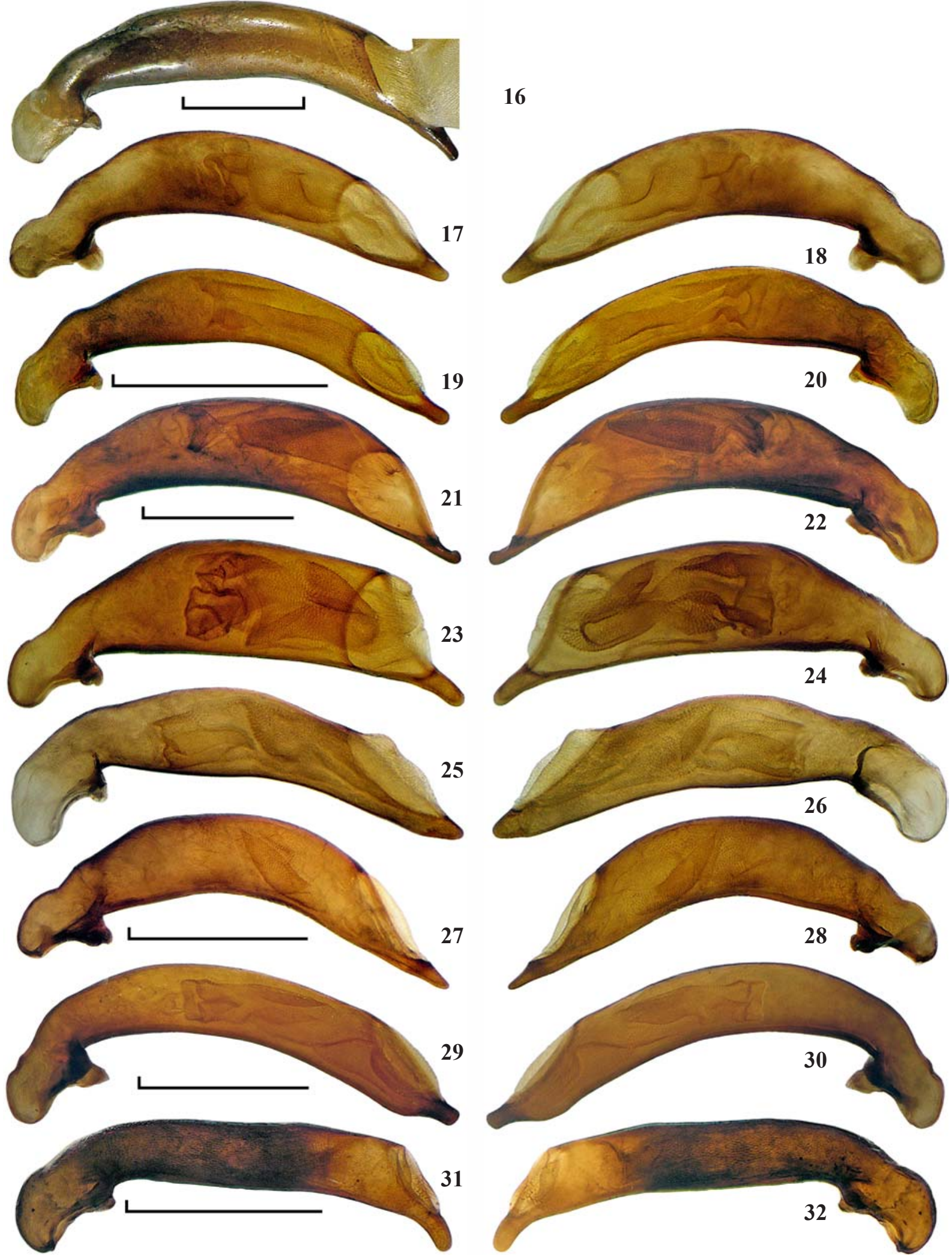

Figs 16-32. Median lobe of aedeagus: 16 - Pericalus funestus; $17-18-P$. ornatus; $19-20-P$. formosanus; $21-22-P$. cordicollis: 23-24 - P. obtusipennis sp.n.; 25-26 - P. amplus; 27-28 - P. baehri nom.n.; 29-30 - P. longicollis; 31-32 - P. cicindeloides; 16, $17,19,21,23,25,27,29,31$ - left aspect; $18,20,22,24,26,28,30,32$ - right aspect. Scale bar $1 \mathrm{~mm}$.

Рис. 16-32. Средняя доля эдеагуса: 16 - Pericalus funestus; $17-18-$ P. ornatus; $19-20-P$. formosanus; $21-22-P$. cordicollis; 23-24 - P. obtusipennis sp.n.; 25-26-P. amplus; 27-28 - P. baehri nom.n.; 29-30-P. longicollis; 31-32-P. cicindeloides; 16, $17,19,21,23,25,27,29,31$ - вид слева; 18, 20, 22, 24, 26, 28, 30, 32 - вид справа. Масштаб 1 мм. 

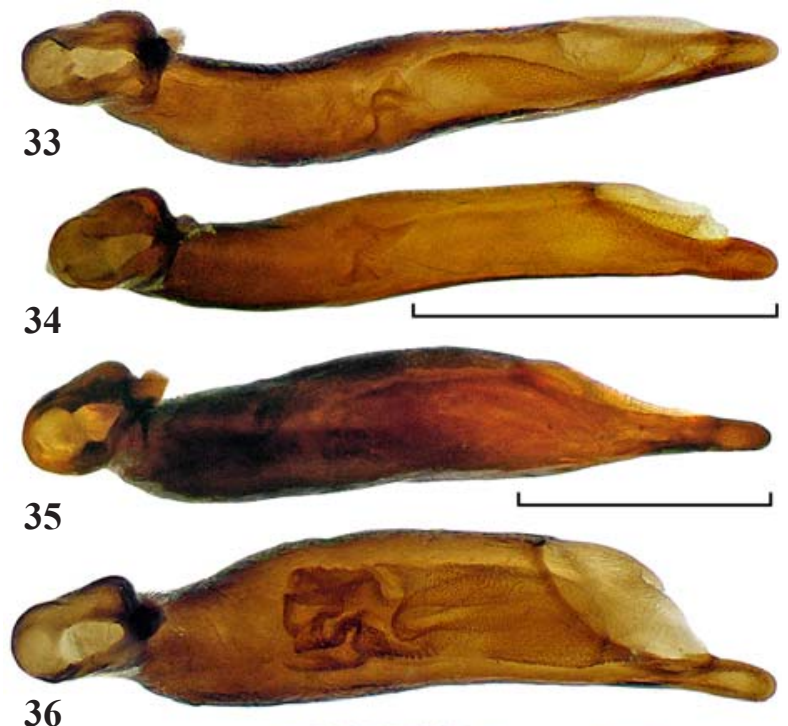

36

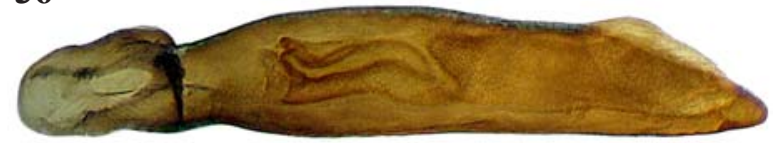

37

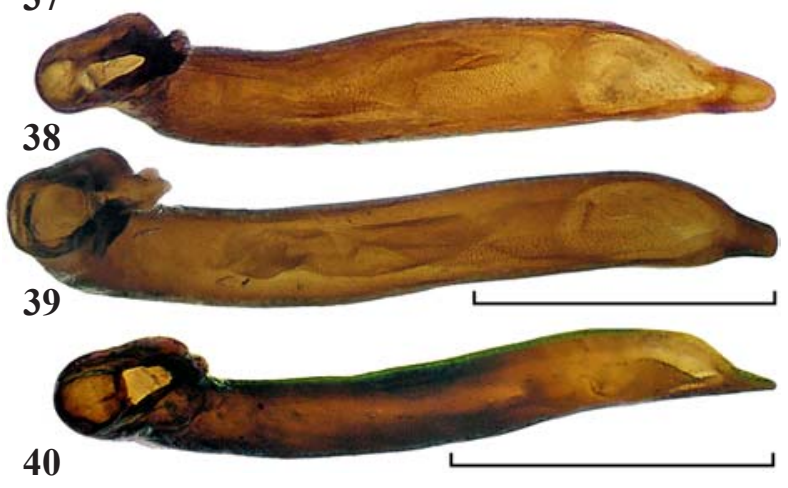

Figs 33-40. Median lobe of aedeagus, ventral aspect: 33 Pericalus ornatus $; 34-P$. formosanus $; 35-P$. cordicollis; $36-$ P. obtusipennis sp.n.; $37-P$. amplus; $38-$ P. baehri nom.n.; 39 - P. longicollis; $40-P$. cicindeloides. Scale bar $1 \mathrm{~mm}$.

Рис. 33-40. Средняя доля эдеагуса, вентрально: 33 - Pericalus ornatus; $34-P$. formosanus; $35-P$. cordicollis; $36-P$. obtusipennis sp.n.; $37-P$. amplus; $38-P$. baehri nom.n.; $39-$ P. longicollis; $40-P$. cicindeloides. Масштаб 1 мм.

sider apically mucronate elytra to be derived, with apically rounded, truncate, or minutely toothed at sutural angle represinting less derived conditions.

The species with dorsal AMLO have the other discussed character states primitive, except for the derived elytral chetome; the elytral pattern is ancestral or nearly so. Of these species, two southern insular ones, $P$. funestus and $P$. cordicollis, have slightly stronger purplish or bluish tinge of the elytra; postmedian spot a bit wider (spanning intervals 4-6 vs. 4-5) and usually closer to the base; and left paramere apically wider, truncate and more or less bifid, which suggests closer relationships of the two species to each other than to the remainder.

The remaining examined species can be divided into two groups. The first one includes $P$. guttatus, $P$. violaceus, $P$. baehri, $P$. longicollis, $P$. cicindeloides, and probably $P$. aeneipennis. They show derived character states, such as bright metallic elytra with mucronate apices, combined with plesiomorphic character, four discal setae present $(P$. cicindeloides), or with $\mathrm{d} 2$ clearly behind the middle. The elytral pattern exhibits various degrees of modification of the basic pattern: the anterior band split into separate spots; or is reduced to two round spots; or no pale colour at all. When the pattern consists of two spots, the anterior one corresponds to the enlarged median part of anterior band, and the posterior, to the postmedian spot on intervals 4-5. P. longicollis and perhaps $P$. aeneipennis have three discal setae, with $\mathrm{d} 2$ at or just behind the middle.

The second group includes P. obtusipennis sp.n. and P. amplus. They differ from each other in elytral chetome (derived or primitive, respectively) and aedeagi. AMLO position is somewhat intermediate, being rather left in the former and dorsal in the latter. Otherwise the two share a distinctive elytral pattern (not too advanced) and background (fairly primitive), and the shape of elytral apices. This character combination suggests closer affinity between P. obtusipennis sp.n. and P. amplus than between these two and $P$. ornatus with its allies.

\section{Key to species of Pericalus s.str.}

1(6) Elytra uniformly black or metallic, with outer angle of apical truncature sharp or toothed (Fig. 15).

2(3) Discal elytral setae three. Elytral apex pointed. Head blue green, pronotum green, elytra aeneous green. BL 9 mm. - East Borneo

P. aeneipennis Louwerens, 1964 (ex descr.)

3(2) Discal elytral setae four.

4(5) Elytral apices pointed opposite stria 1 and separated by a small inward angle; outer angle of apical truncature obtuse, sharp to blunt (Fig. 15). Head nearly smooth along middle and on vertex, each side with 2-3 blunt longitudinal carinae and a vestigial carina between supraocular setae. Apical angles of pronotum produced far forward, acute and rather sharp. Dorsum bright metallic blue or violaceous blue. Legs dark. Elytral microsculpture strongly transverse. BL 8.3-11.6 mm. - Malay Peninsula, Sumatra, Java, Philippines (Palawan, Mindanao, Luzon) ............ P. cicindeloides MacLeay, 1825

5(4) Elytra truncate apically. Apical angles of pronotum projecting but a little. Head and pronotum aeneous, elytra black. Femora pale. Elytral microsculpture isodiametric. BL 8.5-9 mm. - Southern India ...

$$
\text { P. fascinator Andrewes, } 1937 \text { (ex descr.) }
$$

6(1) Elytra with pale pattern (Figs 1-14).

7(10) Elytron with two round pale spots (Fig. 14) and three discal setae.

8(9) Elytral apices rounded; pale spots large, anterior on intervals 4-8, posterior on intervals 4-7. Body black and large, BL 14.5-17.5 mm. — Laos ......

$$
\text { P. dux Andrewes, } 1920
$$

9(8) Elytron pointed at sutural angle; anterior spot on intervals 3-4 to 6-7, posterior one on intervals $4-5$ to 6 (Fig. 14). Dorsum otherwise bright metallic, blue violet, blue green or green; elytra blue violet or violet. Smaller, BL $c a$. 10-12.5 mm. - Malay Peninsula, Sumatra, Borneo, Philippines ................... P. longicollis Chaudoir, 1869

10(7) Elytron (Figs 1-13) with a large pale spot or transverse band in basal half, plus small separate spots: one or two on intervals $4-6$ behind the middle and two before apex on intervals 2-3 and 7-8; anterior band sometimes broken into separate spots as well.

11(14) Interval 6 just behind middle with a separate spot extending clearly further basad than the spot on intervals 4-5 (Figs 5, 10); outer angles of apical truncature obtuse and blunt; 3-4 discal setae present. 
12(13) Elytron with four discal setae and a wide transverse band on intervals 3-7 a third from base; pale colour on odd intervals extends further basad, and on even intervals, further apicad (Fig. 5). Elytra with minutely toothed sutural angles and an obtuse inward angle between angulate apices opposite interval 3 or stria 2 . Pronotal basal angles slightly acute. Body appears more robust due to wide pronotal base, about 1.2 times as wide as apex. BL 8.1-10.3 mm. - Northeastern India and Myanmar to northern Vietnam .......... 2. P. amplus Andrewes, 1937

13(12) Elytron with three discal setae, a very narrow transverse band on intervals 3-6(7), almost broken into separate spots (Fig. 10). Elytral apices truncate and blunt. Pronotal basal angles right to slightly obtuse. Body appears more slender due to pronotum being barely wider at base than at apex. BL 8.6-12 mm. - Northern Vietnam 1. P. obtusipennis sp.n.

14(11) Interval 6 without separate spot behind the middle; three discal setae present.

15(24) Elytron either rounded or truncate apically, or minutely toothed at sutural angle (Figs 1-8). Middle discal seta (d2) at or before middle of elytra. Body mostly black; elytron a third from base with a larger pale spot or wavy transverse band, and with separate spots behind; colour on interval 3 does not extend much further basad than on interval 4 or on intervals 5 and 7.

16(17) Legs and antennae red. Pale colour on intervals 3-4 extends slightly further basad than on intervals 5-6. BL ca. $10 \mathrm{~mm}$. - India (Sikkim, Assam, Andaman Is), Myanmar ........................... P. distinctus Dupuis, 1913

17(16) Legs and antennae or at least femora and antennomeres 1-4 infuscate.

18(19) Elytron a third from base with a very narrow, wavy transverse band almost broken into separate spots (Fig. 8), colour on odd intervals extends further basad than on even ones. Sides of elytra distinctly sinuate a third from base; posterolateral angles toothed. Dorsum black, elytra with very faint blue or purple tinge. BL 13-15.5 mm. Sumatra ..................... 5. P. funestus Andrewes, 1926

19(18) Elytron a third from base with a large pale spot or a wide transverse band, entire or broken (Figs 1-7). Sides of elytra rounded or straight in basal two fifths. Dorsum black, elytra sometimes with faint blue or violaceous tinge.

20(21) Elytron (Fig. 5) with anterior transverse band wide yet broken or almost broken into two spots, of which the one on intervals 5-8 extends further basad than that on intervals $3-$ 4. Elytra black, with faint blue or violaceous tinge, toothed at sutural and at posterolateral angles. Sides of pronotum deeply sinuate and diverging towards basal angles, which are slightly acute and projecting outwards. Genae convex in female yet obtusely angulate in male. BL $12-13.5 \mathrm{~mm}$. North Borneo .................. P. cordicollis Andrewes, 1931

21(20) Elytron anteriorly with a large pale spot or wide transverse band (Figs 1-4, 6-7). Body small, BL $<12 \mathrm{~mm}$. Pronotum nearly parallel-sided before right basal angles.

22(23) Elytron a third from base with a round pale spot or a subtransverse macula occupying intervals $4-6$ and often expanding also onto intervals $2-3$ and 7-8 (Figs 1-4); posterolateral angles mostly pointed or with a small tooth; apices usually rounded, with sutural angle rounded off or very obtuse. Lateral margin of pronotum mostly moderately explanate and slightly yet clearly reflexed behind the middle. BL 8.1-11.1 mm. Aedeagus (Figs 17-18,33) in lateral view much wider medially than basally, with apical lamella tapering. - Northeastern India, Indochina ...... 3. P. ornatus Schmidt-Göbel , 1846
23(22) Elytron with a wide wavy band spanning intervals 3 7 a third from base (Figs 6-7); posterolateral angles sharp but not pointed; apices mostly truncate, with a blunt to pointed denticle at suture. Lateral margin of pronotum moderately to rather widely explanate yet scarcely reflexed. BL 7.8-10.3 mm. Aedeagus (Figs 19-20,34) in lateral view subequally and moderately wide throughout; apical lamella subcylindric and slightly upturned. Taiwan, Vietnam ......... 4. P. formosanus Dupuis, 1913

24(15) Sutural elytral angles spinose (Figs 11-13); middle discal seta (d2) about three fifths from base. Anterior spot on interval 3 extends distinctly further basad than on other intervals.

25(28) Elytron anteriorly with separate pale spots on intervals 4 and 6 distinctly behind those on intervals 3, 5 and 7 (Fig. 11). Eyes a little more protruding, about four fifths longer than wide in dorsal view, and somewhat oblique.

26(27) Elytra black, with faint violaceous or bluish tinge. Frons flat. Frons and vertex with 7-10 wavy longitudinal carinae on each side. BL 11-12.3 mm. - Sumatra, Java, Bali ................................ P. guttatus Chevrolat, 1832

27(26) Elytra bright violaceous. Frons raised; longitudinal carinae between eyes more even and less numerous. BL 10.7-11.5 mm. - Malay Peninsula.

P. violaceus Andrewes, 1926

28(25) Elytra in basal third with an irregular transverse band spanning intervals 3-7 or broken into a few contiguous spots, or reduced to two separate spots on intervals 3 and 4 5 (Figs 12-13). Elytra bright violaceous or violaceous blue. Frons flat. Eyes less protruding, nearly twice as long as wide in dorsal view, almost hemispherical. Head with 8-10 even longitudinal carinae on each side. BL 9.3-11.9 mm. Sumatra, Java, Borneo, Sulawesi ........ P. baehri nom.n.

\section{Pericalus (s. str.) obtusipennis Fedorenko, sp.n.}

Figs 10, 16, 23-24, 36, 41, 54, 67, 72.

MATERIAL. Holotype $0^{7}$ (ZMMU) and six paratypes, $10^{7}$, 5우, labelled: 'N[orthern] Vietnam, Lao Cai Prov[ince]., Hoang Lien Son Mt. ridge, env. Fansipan [Phang Xi Pang] Mt. Tram Ton, $\mathrm{h}=1950-2100,15-30$. VII.2007, leg. D. Fedorenko'.

DESCRIPTION. BL 8.6-12 mm. Body (Fig. 72) shiny black, not or indistinctly sericeous; mandibles vaguely reddish at middle; palps deep red to dark brown, tarsi reddishbrown to rather dark brown; antennae varying from black and only slightly paler apicad to pale brown, gradually infuscated basad to brown; scape black. Elytron a third from base with a narrow transverse yellow band on intervals 3-6(7); pale colour on odd intervals extending towards base but connected with pale on even ones. Behind the band, a small pale spot on interval 6 at middle, another $2 / 5$ from apex, spanning intervals 4-5 (sometimes pale spot on interval 4 lies basad of and separated from spot on interval 5); preapical spots on intervals $2-3$ and 7 subequally distant from apex.

Microsculpture not quite regular, isodiametric and superficial on head, obliterate or vague on neck and at middle of vertex; pronotal disc with very superficial, slightly transverse meshes that become nearly isodiametric in paramedian foveae and over base; sides of pronotum with rather coarse meshes becoming isodiametric or very slightly longitudinal on explanate lateral margins; elytra with fine and strongly transverse meshes becoming less superficial and less transverse on outer two intervals, reflexed lateral margin with pronounced microsculpture consisting of barely transverse to isodiametric meshes.

Head. Eyes large; genae long, oblique, meeting both neck and eye at highly obtuse, blunt angle. Dorsum longitudinally 
strigose, each side with 4-5 irregular longitudinal carinae on clypeus and 8-10, mostly 9, slightly uneven carinae on frons and vertex, these diverging slightly behind; inner carinae being more or less wavy. Neck constriction shallow yet distinct.
Pronotum broadest a fourth from apex, PLw/PL 0.23-0.28 $(0.25 \mathrm{n}=5)$, PW/PL 1.66-1.73 (1.70), very slightly wider than head, PW/HW 0.99-1.08 (1.03). Base a little wider than apex, $\mathrm{PWb} / \mathrm{a} 1.06-1.17$ (1.12), truncate, with sides indistinctly to
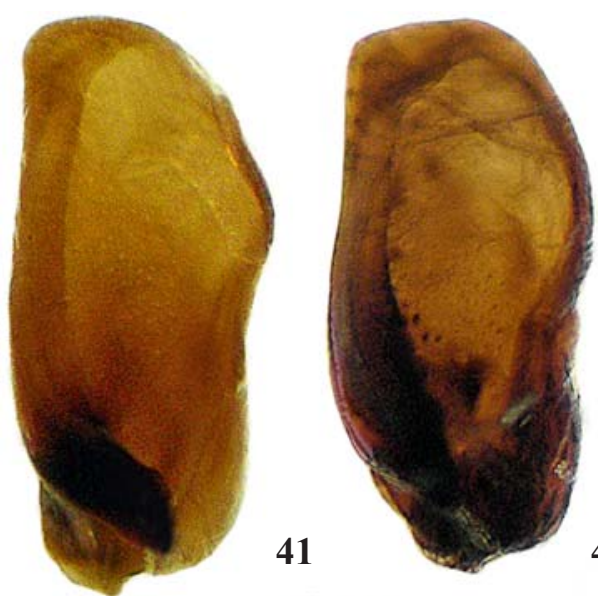

42
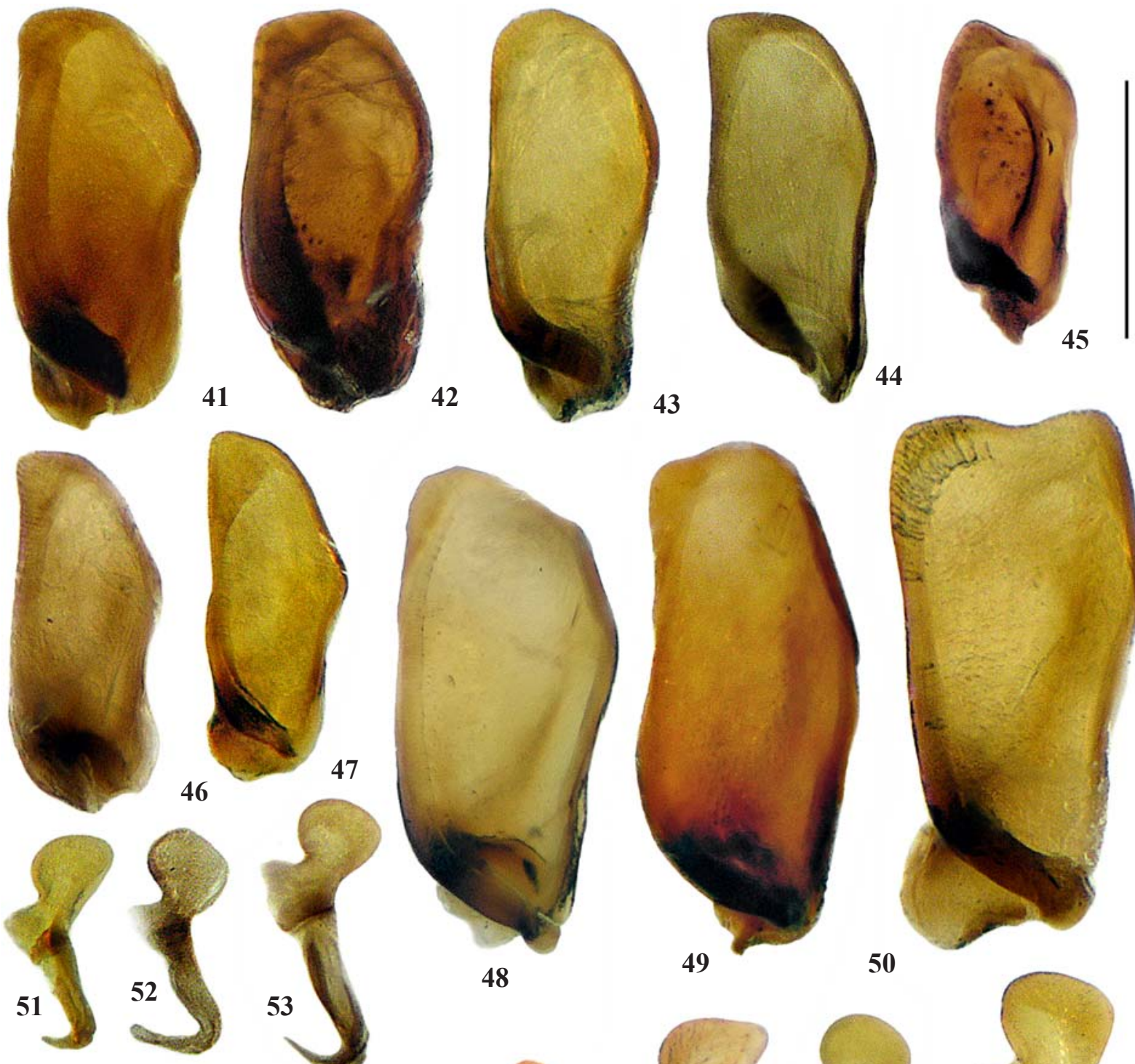

44

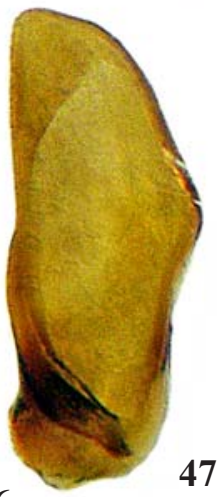

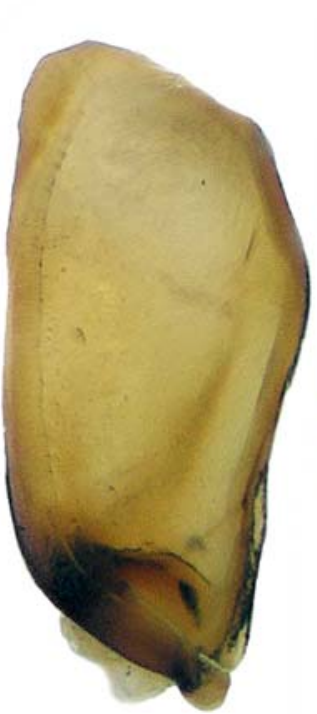

48

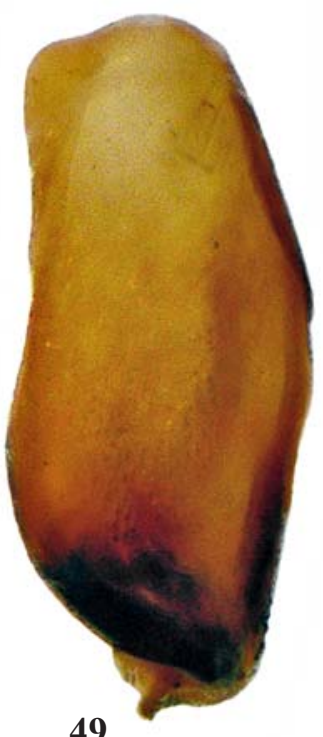

49

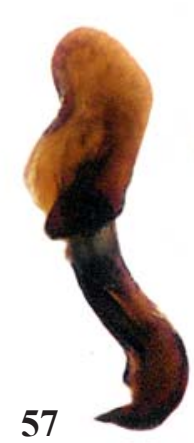

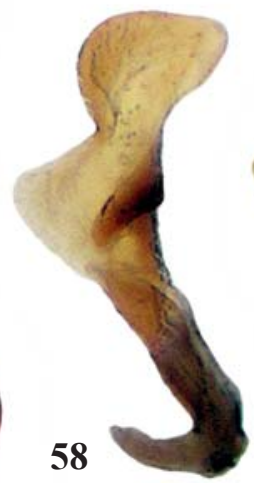

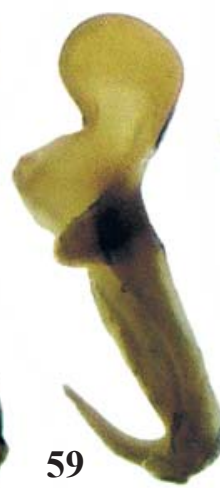

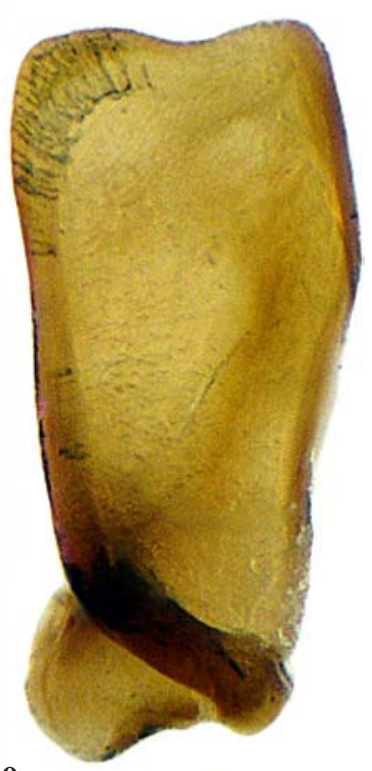

50

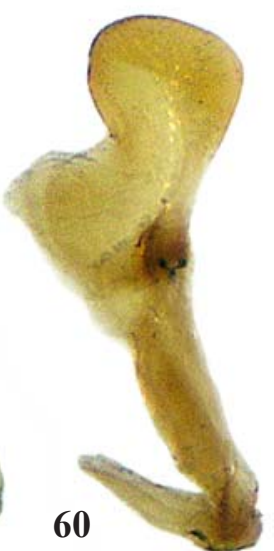

Figs 41-60. Right (41-50) and left (51-60) parameres: 41, 54 - Pericalus obtusipennis sp.n.; 42, 55 - P. baehri nom.n.; 43,56 P. guttatus; 44, $53-$ P. amplus; 45, $57-$ P. cicindeloides; 46, $52-$ P. ornatus; 47, $51-$ P. formosanus; 48, $58-P$. longicollis; 49, $59-P$. cordicollis; 50, $60-P$. funestus. Scale bar $0.5 \mathrm{~mm}$.

Рис. 41-60. Правая (41-50) и левая (51-60) парамеры: 41, 54 - Pericalus obtusipennis sp.n.; 42, 55 — P. baehri nom.n.; 43, 56 P. guttatus; 44, $53-$ P. amplus; 45, 57 - P. cicindeloides; 46, 52 - P. ornatus; 47, $51-$ P. formosanus; 48, 58 - P. longicollis; 49, $59-P$. cordicollis; 50, $60-P$. funestus. Масштаб 0.5 мм. 
slightly oblique. Apex deeply emarginate, straight or barely concave between apical angles, these projecting and moderately rounded. Sides well rounded in apical four fifths, sinuate or subsinuate behind. Basal angles sharp and right or barely more than right. Disc convex inside paramedian foveae, otherwise flattened. Lateral margins widely explanate, strongly reflexed

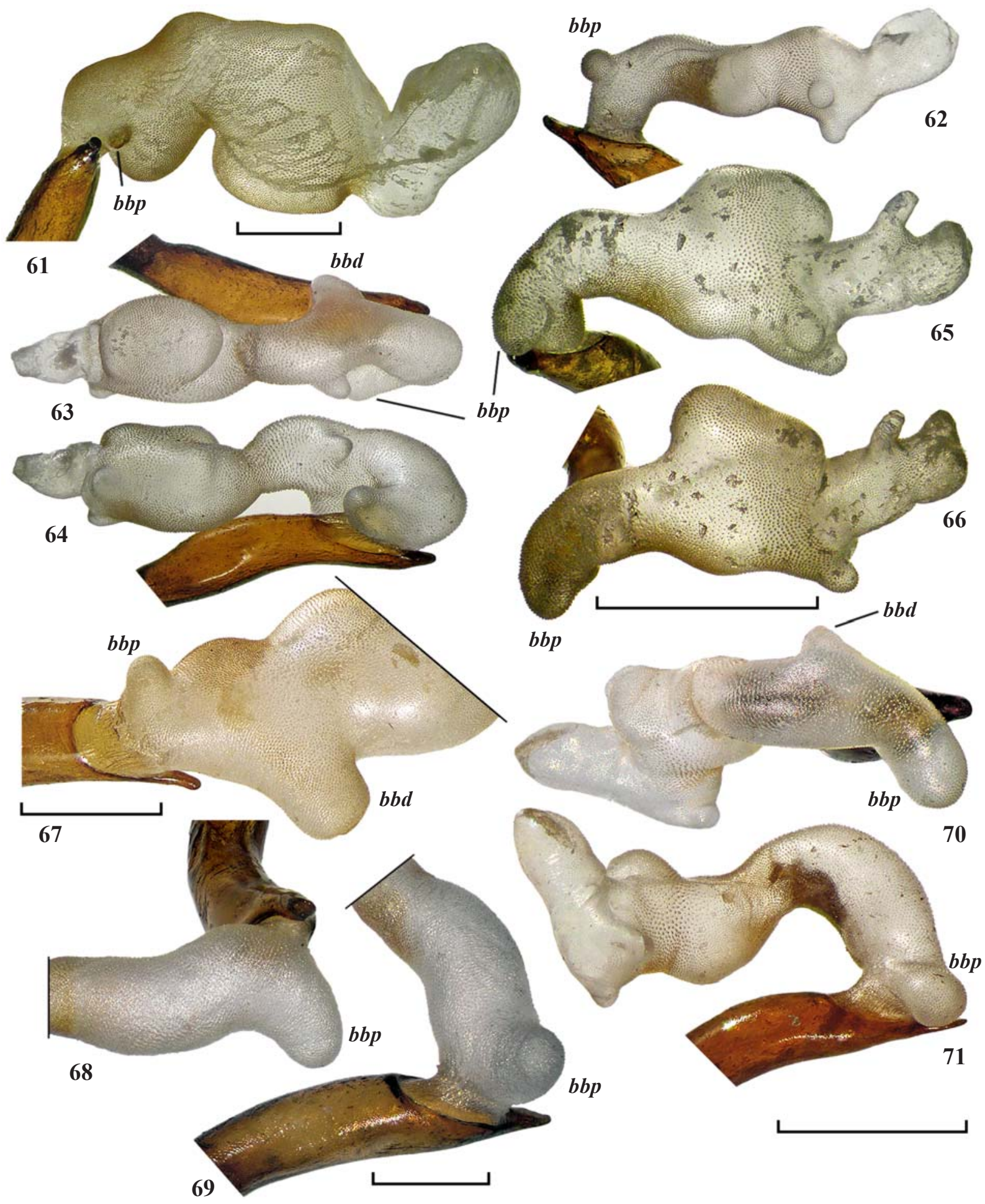

Figs 61-71. Everted and inflated internal sac of aedeagus: $61-$ Pericalus funestus; $62-P$. ornatus; $63-64-P$. amplus; $65-66-$ P. formosanus; $67-P$. obtusipennis sp.n.; 68-69 - P. guttatus; 70-71 - P. baehri nom.n.; bbd - distal basal bulb; bbp - proximal basal bulb. Scale bar $1 \mathrm{~mm}$.

Рис. 61-71. Вывернутый и раздутый внутренний мешок эдеагуса: 61 - Pericalus funestus; 62 - P. ornatus; 63 - 64 — P. amplus; 65-66 - P. formosanus; 67 - P. obtusipennis sp.n.; 68-69 - P. guttatus; 70-71 - P. baehri nom.n.; bbd - дистальный базальный пузырь; $b b p$ - проксимальный базальный пузырь. Масштаб 1 мм. 
in basal 1/2-3/5, less so at, and including, apical angles. Apical transverse impression deep and arcuate backwards, basal transverse impression very deep, widely $\mathrm{W}$-shaped, both adjoining deep and large paramedian foveae. Lateral grooves and paralateral lines subequally shallow, but traceable in basal three to four fifths. Apical bead obliterate medially, lateral bead absent. Surface more or less finely cross-striated medially, rugose or coarsely cross-striated outside paramedian foveae.

Elytra oval, EL/EW 1.32-1.36 (1.35), EW/PW 1.511.57 (1.53), broadest behind the middle. Base truncate, humeri distinct, slightly angulate, sides well rounded just behind, then straight and diverging, widely rounded posteriorly. Apical truncature oblique, sinuate, with outer angles obtuse and blunt or rounded; apices separately and narrowly rounded each. Striae very deep and smooth; intervals convex to very convex. Interval 3 with three discal setae, D1/EL $0.10-0.17$ (0.13), D2/EL 0.48-0.59 (0.53).

Aedeagus (Figs 16, 23-24, 36, 41, 54). Median lobe stout, with large transverse apical orifice. Right paramere

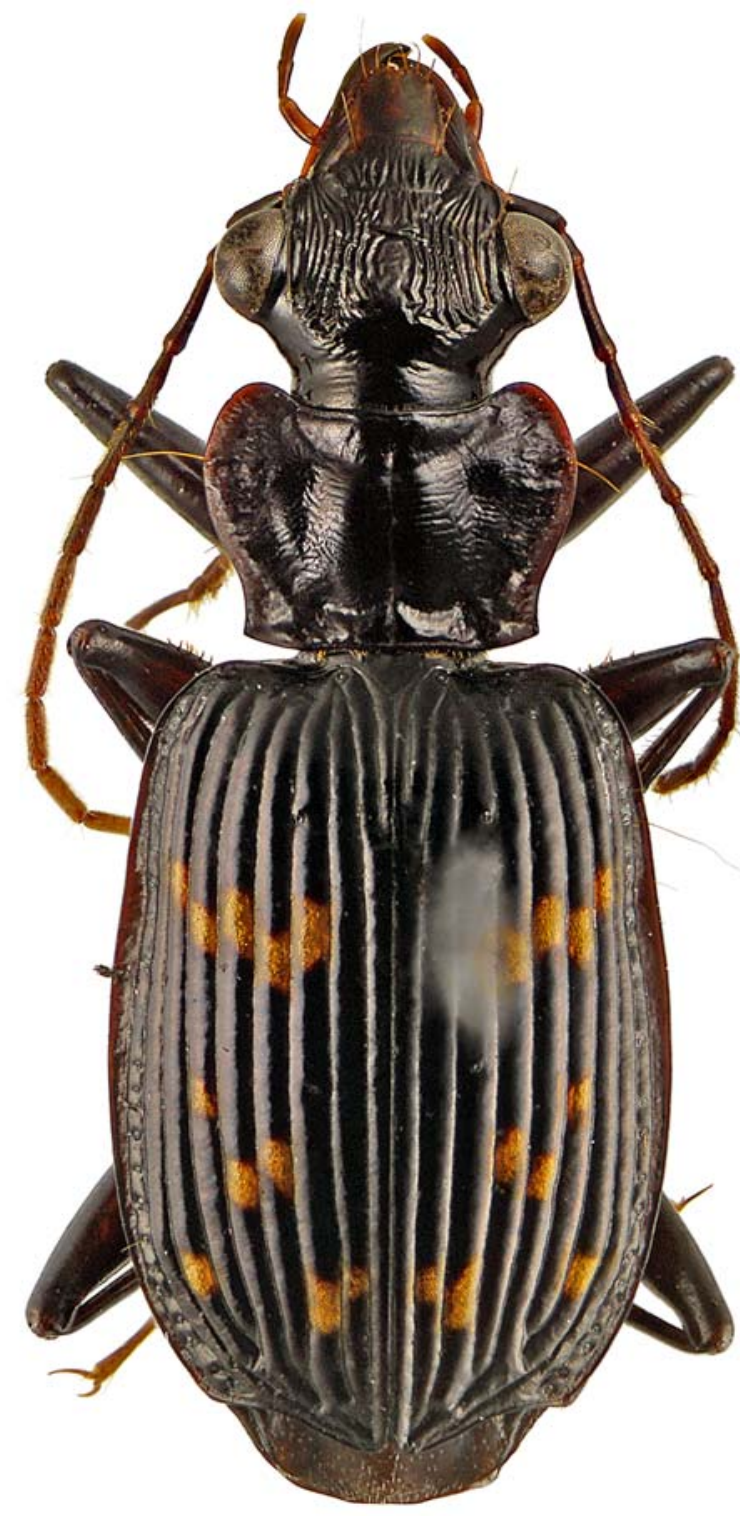

Fig. 72. Pericalus obtusipennis sp.n., dorsal habitus. Рис. 72. Pericalus obtusipennis sp.n., габитус, дорзально. triangular ventro-apically. Everted and inflated internal sac large, more so apically, with a small proximal basal bulb and a large distal basal bulb (Fig. 67).

DIAGNOSIS. Readily identifiable by the following elytral characters: a distinctive colour pattern, obtuse and rounded posterolateral angles, and three discal setae (see also the key). Aedeagus is also distinctive in both shape and structure.

DISTRIBUTION. Known from the type locality only.

NAME. Refers to obtuse outer angle of the elytron.

HABITATS AND HABITS. All specimens were taken on a larger log and under fallen bark fragments of a standing dead tree in a rainforest.

\section{Pericalus (s. str.) amplus Andrewes, 1937}

Figs 5, 25-26, 37, 44, 53, 63-64.

Andrewes, 1937: 186 (Assam and Burma); Jedlička, 1963: 377. MATERIAL. $20^{7} 0^{7}$ (SIEE): Northern Vietnam, Phu Tho, 90 $\mathrm{km} \mathrm{W}$ of Hanoi, Xuan Son National Park, $21^{\circ} 07^{\prime} 52^{\prime \prime N} 104^{\circ} 57^{\prime} 07^{\prime \prime E}$, $\mathrm{h}=400-470 \mathrm{~m}, 6-15$. VI.2014, D. Fedorenko leg; $1 \mathrm{spm}$ (ZISP): mountains $50 \mathrm{~km}$ NO of Thai Nguen, 8.II.1963, Kabakov leg.; 2 spms (ZISP), same location, 8.III.1963 and $300 \mathrm{~m}$, 5.II.1963.

COMMENTS. This species was described from 13 syntypes, five from Assam and eight from Burma. Of them, two Indian specimens were said to be found under bark or in rotten wood. The two males listed above were taken on fallen trees clear of the ground. This is the first record of the species in Vietnam.

\section{Pericalus (s. str.) ornatus Schmidt-Göbel, 1846}

Figs 1-4, 17-18, 33, 46, 52, 62.

Schmidt-Göbel , 1846: 86; Dupuis, 1913: 83; Bates, 1892: 411; Andrewes, 1923: 49; 1937: 185; 1946: 12; Jedlička, 1963: 379.

MATERIAL. $63 \sigma^{7} \sigma^{7}+9$ (SIEE): Vietnam, Phu Tho, $\sim 90 \mathrm{~km}$ W of Hanoi, Xuan Son NP, $21^{\circ} 07^{\prime} 58^{\prime \prime N} 104^{\circ} 55^{\prime} 45^{\prime \prime} \mathrm{E}, \mathrm{h}=300 \mathrm{~m}$, river valley, 6-15.VI.2014; Kon Tum, Chu Mom Ray NP, 14³0'N $107^{\circ} 42^{\prime} 30^{\prime \prime E}$, ngok To Lum Mt, $\mathrm{h}=1100-1350 \mathrm{~m}$, 28.III4.IV.2015; same data but $107^{\circ} 43^{\prime} 45^{\prime \prime} \mathrm{E}, \mathrm{S}$ of Chu Mom Ray Mt, $\mathrm{h}=1000 \mathrm{~m}$; Kon Plong District, $14^{\circ} 44^{\prime} \mathrm{N}, 108^{\circ} 18^{\prime} \mathrm{E}$, env. ngoc Boc $1 \mathrm{Mt}, \mathrm{h}=1100-1200 \mathrm{~m}, 8-23 . I V .2015$; Gia Lai, $40 \mathrm{~km}$ ENE of Pleiku, 14²1 '11"N 108 $18^{\prime} 54^{\prime \prime E}$, Kon Ka Kinh NP, h=890 m, 9-22.V.2016; same but $14^{\circ} 13^{\prime} 09^{\prime \prime N} 108^{\circ} 19^{\prime} 48 " \mathrm{E}, \mathrm{h}=1470 \mathrm{~m}$, 21-30.V.2017; same locality but $\sim 55 \mathrm{~km}$ ENE of Pleiku, $14^{\circ} 19^{\prime}$ $06^{\prime \prime N} 108^{\circ} 26^{\prime} 44^{\prime \prime} \mathrm{E}, \mathrm{h}=890 \mathrm{~m}, 8-20 . \mathrm{V} .2017$; same but $14^{\circ} 17^{\prime} 07^{\prime \prime} \mathrm{N}$ $108^{\circ} 27^{\prime} 55^{\prime \prime} \mathrm{E}, \mathrm{h}=830 \mathrm{~m}, 8-20 . V .2017$; Dak Lak, Chu Yang Sin NP, $12^{\circ} 23^{\prime} 48^{\prime \prime} \mathrm{N} 108^{\circ} 21^{\prime} \mathrm{E}$, upper flow of Krong Kmar river, h=1000 m, 1-14.IV.2012 and 18.III-2.IV.2013; Lam Dong, Bi Doup - Nui Ba Nature Reserve, $12^{\circ} 10^{\prime} 44^{\prime \prime N} 108^{\circ} 40^{\prime} 44^{\prime \prime}$ E, env. Long Lanh, $\mathrm{h}=1400-1600 \mathrm{~m}, 1-21 . \mathrm{IV} .2008$ and 29.IV-10.V. 2009; Binh Phuoc, Bu Gia Map NP, 12¹1'7"N 107'12'21"E, $\mathrm{h}=350-540 \mathrm{~m}, 11-12 . I V .2009$ and 26.IV-5.V.2013; Dong Nai, Cat Tien NP, $11^{\circ} 25^{\prime} 18^{\prime \prime} \mathrm{N} 107^{\circ} 25^{\prime} 44^{\prime \prime E}, 11-18 . V I .2005$. O'오 Myanmar, env. Maymyo, 700-900 m, 4-5.03.1996, leg. S. Kurbatov. Aedeagus examined in 14 males.

DISTRIBUTION. A common species known from northwestern India (Sikkim, Assam, Meghalaya), Myanmar, Thailand, Cambodia, Laos, and Vietnam.

\section{Pericalus (s. str.) formosanus Dupuis, 1913}

Figs 6-7, 19-20, 34, 47, 51, 65-66.

Dupuis, 1913: 83; Jedlička, 1963: 379.

MATERIAL. Five photographed syntypes (Senkenberg Deutsches Entomologisches Institute [http://digitmuse.nmns.edu.tw]): $\sigma^{7}$, labelled: 'Chip Chip, II [hw] Formosa, Sauter...07-09', 'TYPUS', 'Pericalus formosanus Dupuis [hw], Dupuis det.' 'Syntypus', 'DEI Coleoptera, \# 200411'; 1 spm with labels: 'Hoozan, Formosa, H. Sauter', 'PARATYP.', 'Pericalus formosanus Dupuis [hw], Dupuis det.', 'Syntypus', 'DEI Coleoptera, \# 200411'; 3 spms, same data, except for '\# 200412' or '\# 200413', or '\# 200412' on the last label, respectively. 
Additional material. 130 $0^{7}$ or (SIEE): Vietnam, Kon Tum, Kon Plong District, $14^{\circ} 44^{\prime} \mathrm{N}, 108^{\circ} 18^{\prime} \mathrm{E}$, env. ngoc Boc $1 \mathrm{Mt}, \mathrm{h}=1100$ $1200 \mathrm{~m}, 8-23 . I V .2015 ;$ Gia Lai, $40 \mathrm{~km}$ ENE of Pleiku, 14²12'11"N $108^{\circ} 18^{\prime} 54 " \mathrm{E}$, Kon Ka Kinh NP, h=890 m, 9-22.V.2016; same locality but $\sim 40 \mathrm{~km}$ ENE of Pleiku, $14^{\circ} 19^{\prime} 06^{\prime \prime} \mathrm{N} 108^{\circ} 26^{\prime} 44^{\prime \prime} \mathrm{E}, \mathrm{h}=890$ m, 8-20.V.2017; Binh Phuoc, Bu Gia Map NP, 12 $11^{\prime} 7 " \mathrm{~N}$ $107^{\circ} 12^{\prime} 21^{\prime \prime E}, \mathrm{~h}=350-540 \mathrm{~m}, 16-17 . I V .2009 ; 28 . I V-4 . V .2013$. Aedeagus examined in five males.

DISTRIBUTION. Southern China (Taiwan); Vietnam country record.

HABITATS AND HABITS. More sporadic and less common than $P$. ornatus, including in habitats where those cooccurs.

COMMENTS. Very similar to P. ornatus. Some specimens of these two species are reliably identifiable from aedeagi only (compare Fig.62 with Figs 65-66). The median lobe of aedeagus of $P$. formosanus is narrower in lateral view and less curved at base in ventral view than that of $P$. ornatus. The apical lamella in ventral view is more parallel-sided and more widely rounded at tip ( $v s$. subtriangular). The everted and inflated internal sac is strongly dilated apically, with a large proximal basal bulb (vs. subequally wide throughout, with a small bulb).

\section{Pericalus (s. str.) funestus Andrewes, 1926} Figs 8, 16, 50-60, 61.

Andrewes, 1926: 284 (Gunung Singgalang, Sumatra); Baehr, 2000: 34.

MATERIAL. $\sigma^{\top}$ (ZISP): Indonesia: Sumatra, Jambi, $35 \mathrm{~km} \mathrm{~N}$ of Sungaipenuh, env. Kerinci-Seblat Nat. Park, Mt. Kerinci, 15002000 m, 18-22.XI.1999, A.V. Gorochov leg.

DISTRIBUTION. A rare species hitherto known from two localities in Sumatra. There is also a female from Sumatra determined by Alexander Anichtchenko [www: carabidae.org]: Sumatera Utara, Berastagi, $1500 \mathrm{~m}$, 03ำ12'17"N 09832'34"E, 13.I.2011, R. Cibulskis leg., a somewhat deformed teneral specimen [Anichtchenko, pers. comm.].

COMMENTS. The species was described from four specimens taken at $5800 \mathrm{ft}(\sim 1770 \mathrm{~m})$ elevation. Subsequently [Baehr, 2000] it was placed, along with three Malayan species ( $P$. guttatus Chevrolat, 1832, P. violaceus Andrewes, 1926, and P. imitator Baehr, 2000) in the guttatus-complex. However, unlike other members of the complex, $P$. funestus has elytra rounded apically ( $v s$. mucronate), discal seta $\mathrm{d} 2$ at or before the middle ( $v s$. clearly behind the middle), and pale patch on interval 3 not much extending basad of the rest of the band; based on this character combination we move $P$. funestus from the guttatus-complex closer to $P$. ornatus and allies.

There was a confusion involving $P$. violaceus and $P$. imitator. According to the original description [Andrewes, 1926], P. guttatus v. violaceus specimens originated from multiple localities, among them 'MALAY PENINSULA (Dr. M. Cameron), 2 ex., including type, in my collection'. This means that the holotype ('type') was originally designated. Subsequently, Baehr [2000] erroneously designated a paratype ('cotype') of $P$. guttatus v. violaceus from 'Fort de Kock, W Sumatra...' as the lectotype of $P$. violaceus; and erroneously included a specimen labelled 'Co-type, Malay Penin. ... Cameron, ...' in the type series of $P$. imitator. Hence, we propose P. baehri nom.n. as the replacement name for $P$. violaceus Baehr, 2000, a junior homonym of $P$. violaceus Andrewes, 1926 (= P. imitator Baehr, 2000, syn.n.). The specimen designated as the 'lectotype' of P. violaceus by Baehr [2000] is in fact the holotype of $P$. baehri nom.n.
The member species of the guttatus-complex are generally allopatric. Among them, P. baehri nom.n. is widespread from Sumatra and Java to Borneo and Celebes and common there; $P$. violaceus is only known from a few localities in the Malay Peninsula, while P. guttatus is its southern insular counterpart from Sumatra, Java, and Bali. However, there is just one Sumatra record of this species, vs. seven of P. baehri nom.n. (as $P$. violaceus) [Andrewes, 1933], which suggest that $P$. guttatus may be uncommon there.

The distribution patterns of the three species, and the fact that $P$. guttatus and $P$. violaceus show greater similarity to each other than to $P$. baehri nom.n., suggest that subspecies status may be more appropriate for the former two. However, I will refrain from restoring the infraspecific rank of $P$. violaceus until more material is available.

ACKNOWLEDGEMENTS. I am indebted to Dr. Boris Kataev (ZISP) for the loan of material under his care and to the late Alexei Klimenko (Tver) for donating specimens of $P$. cordicollis and P. longicollis. I also thank Vassili Belov (College Station, TX USA) for suggestions that have improved the manuscript. The study was supported by the Russian Academy of Sciences Biodiversity Program.

\section{References}

Andrewes H.E. 1920. Notes sur les Carabiques Orientaux. - I // Ann. Soc. Ent. Belg. T.60. P.22-28.

Andrewes H.E. 1923. On the types of Carabidae described by Schmidt-Goebel in his Faunula Coleopterorum Birmaniae // Trans. Ent. Soc. London. P.1-63.

Andrewes H.E. 1926. Papers on Oriental Carabidae.-XXVIII // Ann. \& Mag. Nat. Hist. Ser.9. Vol.18. P.273-290.

Andrewes H.E. 1931. Carabidae of Mt. Kinabalu North Borneo // J. Feder. Malay Museums. Vol.16. Pts3-4. P.431-485.

Andrewes H.E. 1933. A Catalogue of the Carabidae of Sumatra // Tidschr. Entomol. Jg.76. S.319-382.

Andrewes H.E. 1937. Keys to some Indian genera of Carabidae (Col.). XI. The genera Pericalus and Catascopus // Proc. R. Ent. Soc. London. Ser.B. Vol.6. Pt.10. P.185-190.

Andrewes H.E. 1946. Entomological results from the Swedish Expedition 1934 to Burma and British India // Arkiv Zool. Bd.38A. No.20. P.1-49.

Baehr M. 1994. Revision of the subgenus Coeloprosopus Chaudoir of the ground beetle genus Pericalus Macleay (Coleoptera, Carabidae, Lebiinae) // Mitt. Münch. Ent. Ges. Bd.84. S.13-58.

Baehr M. 2000. Review of the Pericalus guttatus-complex (Insecta, Coleoptera, Carabidae, Lebiinae) // Spixiana. Vol.23. S.33-39.

Bates H.W. 1892. Viaggio di Leonardo Fea in Birmania e regione vicine. XLIV. List of the Carabidae // Ann. Mus. Stor. Nat. Genova. Ser.2. Vol.12 (32). P.267-428.

Chaudoir M. 1869. Mémoire sur les Thyréoptérides // Annales de la Société Entomologique de Belgique. T.12. P.113-162.

Chevrolat A. 1832. Classe IX. [Insectes. Notice XLVI] // Magasin de Zoologie. Vol.2. 2pp. Pl.46.

Dupuis P. 1913. H. Sauter's Formosa-Ausbeute Carabidae ( $3^{\mathrm{e}}$ contribution) // Annales de la Société Entomologique de Belgique. T.72. P.81-87.

Gemminger M., Harold E.v. 1868. Catalogus Coleopterorum hucusque descriptorum synonymicus et systematicus. T.1. Cicindelidae-Carabidae. Monachii: E.H. Gummi. xxxvi+424pp+8pp.

Jedlička A. 1963. Monographie der Truncatipennen aus Ostasien. Lebiinae - Odacanthinae - Brachininae (Coleoptera, Carabidae) // Entomol. Abh. Staatl. Mus. Dresden. Bd.28. No.7. S.269-579.

MacLeay W.S. 1825. Annulosa Javanica. London. P.I-XII, 1-50.

Schmidt-Göbel H.M. 1846. Faunula Coleopterorum Birmaniae, adjectis nonnulis Bengaliae indigenis. P.I-VIII+1-94. P1.I-III. 